\title{
Synthesis, Spectral and Electrochemical Properties and DFT Studies of Two Complexes of Ruthenium with Bis-2,3-(2-Pyridyl)Pyrazine and 4-Picoline
}

\author{
CHHANDASI GUHAROY SARKAR ${ }^{*}$ \\ Department of Chemistry, Taki Government College, Taki - 743429, West Bengal, India \\ E-mail: chhandasi_guharoy@yahoo.co.in \\ http://dx.doi.org/10.13005/ojc/320313
}

(Received: April 18, 2016; Accepted: May 29, 2016)

\begin{abstract}
Reaction of bis-2,3-(2-pyridyl)pyrazine $(\mathrm{L})$ with $\left[\mathrm{Ru}(\mathrm{dmso})_{4} \mathrm{Cl}_{2}\right]$ in presence of 4-picoline $\left(\mathrm{L}_{1}\right)$ affords mixed- ligand complexes of the type $\left[\mathrm{Ru}_{2} \mathrm{~L}\left(\mathrm{~L}_{1}\right)_{4} \mathrm{Cl}_{4}\right]$ in which ligand, $\mathrm{L}$ binds to the metal center in the bridging, bidentate $\mathrm{N}, \mathrm{N}$ fashion forming two five-membered chelate rings. Along with $\left[\mathrm{Ru}_{2} \mathrm{~L}\left(\mathrm{~L}_{1}\right)_{4} \mathrm{Cl}_{4}\right]$, another complex of the type $\left[\mathrm{Ru}\left(\mathrm{L}_{1}\right)_{2}(\mathrm{dmso})_{2} \mathrm{Cl}_{2}\right]$ is formed. All the complexes are diamagnetic, and show characteristic ${ }^{1} \mathrm{H}$ NMR signals and intense MLCT transitions in the visible region. DFT studies reveal that the HOMO of the complexes is mostly based on the metal center while the LUMO has maximum contribution from the bonded 4-picoline ligand. Cyclic voltammetry on these complexes shows a $\mathrm{Ru}(\mathrm{II})-\mathrm{Ru}(\mathrm{III})$ oxidation on the positive side of SCE followed by a reduction of the coordinated 4-picoline ligand on the negative side of SCE.
\end{abstract}

Keywords: bis-2,3-(2-pyridyl)pyrazine, $\left[\mathrm{Ru}(\mathrm{dmso})_{4} \mathrm{Cl}_{2}\right]$, spectral and electrochemical properties, DFT studies.

\section{INTRODUCTION}

There has been considerable current interest in the synthesis of platinum metal complexes ${ }^{1-13}$ having fascinating catalytic ${ }^{6,7,12}$, biological ${ }^{11,12}$ and photophysical/photochemical ${ }^{12}$ properties. The coordination environment around the central metal often influences these properties of the complexes. So, in this regard, choice of the ligand system is very important. Keeping this background in mind, in the present study a nitrogen-containing aromatic heterocycle viz. bis-2,3-(2-pyridyl)pyrazine (L, I) has been selected as the principal ligand. This ligand is a potential bridging $\mathrm{N}, \mathrm{N}$-donor which binds to the metal center forming a stable five-membered chelate ring ${ }^{14-18}$. To interact with this ligand $(L, I)$, $\left[\mathrm{Ru}(\mathrm{dmsO})_{4} \mathrm{Cl}_{2}\right]$ has been chosen because of its demonstrated ability to accommodate heterocyclic neutral ligands via displacement of the coordinated moities ${ }^{19-21}$. It may be worth mentioning here that ruthenium chemistry is also important ${ }^{22-41}$ largely due to their interesting redox ${ }^{35}$, catalytic $22,24,30,38,41$, 
photophysical/photochemical ${ }^{37}$ and biological properties $^{23,33,40}$. The primary objective of the present study has been to synthesize mixed-ligand complexes of ruthenium incorporating ligand $I$ and find out the coordination mode of ligand $I$ in them. Reaction of bis-2,3-(2-pyridyl)pyrazine (L, I) with $\left[\mathrm{Ru}(\mathrm{dmsO})_{4} \mathrm{Cl}_{2}\right]$ in presence of one suitable blocker ligand viz. 4-picoline $\left(\mathrm{L}_{1}, \mathrm{II}\right)$, which is a monodentate nitrogen donating ligand have indeed afforded mixed- ligand complexes of the type $\left[\mathrm{Ru}_{2} \mathrm{~L}\left(\mathrm{~L}_{1}\right)_{4} \mathrm{Cl}_{4}\right]$ in which ligand $I$ has been found to bind to the metal center in the bridging, bidentate $\mathrm{N}, \mathrm{N}$ fashion forming two five-membered chelate rings in the complex. Along with $\left[\mathrm{Ru}_{2} \mathrm{~L}\left(\mathrm{~L}_{1}\right)_{4} \mathrm{Cl}_{4}\right]$, another complex of the type $\left[\mathrm{Ru}\left(\mathrm{L}_{1}\right)_{2}(\mathrm{dmso})_{2} \mathrm{Cl}_{2}\right]$ has also been obtained. The present report deals with the chemistry of these complexes with special reference to their synthesis, characterization, spectral and electrochemical properties and DFT studies.

\section{MATERIALS AND METHODS}

Commercial ruthenium trichloride was purchased from Arora Matthey, Kolkata, India. The ligands 4-picoline and bis-2,3-(2-pyridyl)pyrazine were obtained from sigma-aldrich. $\left[\mathrm{Ru}(\mathrm{dmso})_{4} \mathrm{Cl}_{2}\right]$ was prepared following a reported procedure ${ }^{42}$. All other chemicals and solvents were reagent grade commercial materials and were used as received. Purification of acetonitrile and dichloromethane, and preparation of tetrabutylammonium perchlorate (TBAP) for electrochemical work were performed as reported in the literature ${ }^{43,44}$. Microanalyses $(\mathrm{C}, \mathrm{H}, \mathrm{N})$ were performed using a Heraeus Carlo Erba 1108 elemental analyzer. Mass spectra were recorded with a Micromass LCT electrospray (Qtof Micro YA263) mass spectrometer by electrospray

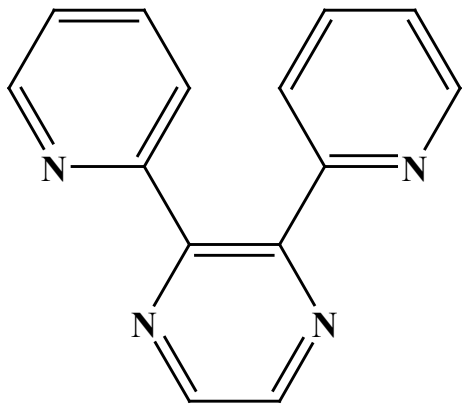

।

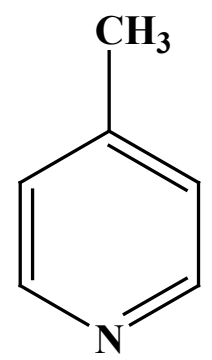

II ionization method. ${ }^{1} \mathrm{H}$ NMR spectra were recorded in $\mathrm{CDCl}_{3}$ solution on a Bruker Avance DPX 300 NMR spectrometer using TMS as the internal standard. IR spectra were obtained on a Shimadzu FTIR-8300 spectrometer with samples prepared as $\mathrm{KBr}$ pellets. Electronic spectra were recorded on a JASCO V-570 spectrophotometer. Optimization of ground state structures and energy calculations for all the complexes were carried out by density functional theory (DFT) method using the GAUSSIAN 03 package ${ }^{45}$, where B3LYP was chosen as the basis function and $631 \mathrm{~g}(\mathrm{~d}, \mathrm{p})$ basis set was taken for $\mathrm{H}, \mathrm{C}$ and $\mathrm{N}$, and SDD basis set for Ru. Electrochemical measurements were made using a $\mathrm{CH}$ Instruments model $600 \mathrm{~A}$ electrochemical analyzer. A platinum disc working electrode, a platinum wire auxiliary electrode and an aqueous saturated calomel reference electrode (SCE) were used in the cyclic voltammetry experiments. All electrochemical experiments were performed under a dinitrogen atmosphere. All electrochemical data were collected at $298 \mathrm{~K}$ and are uncorrected for junction potentials.

\section{Synthesis of Complexes}

Synthesis of $\left[R u_{2} L\left(L_{1}\right)_{4} \mathrm{Cl}_{4}\right]$ and $\left[\mathrm{Ru}\left(\mathrm{L}_{1}\right)_{2}(\mathrm{dmsO})_{2} \mathrm{Cl}_{2}\right]$

The ligand bis-2,3-(2-pyridyl)pyrazine ( $28.45 \mathrm{mg}, 0.12 \mathrm{mmol}$ ) was dissolved in ethanol (40 $\mathrm{mL}$ ) and 4-picoline (56.53 mg, $0.61 \mathrm{mmol}$ ) was added to it followed by the addition of $\left[\mathrm{Ru}(\mathrm{dmso})_{4} \mathrm{Cl}_{2}\right](100$ $\mathrm{mg}, 0.30 \mathrm{mmol}$ ). The resulting mixture was refluxed for $4 \mathrm{~h}$ to produce a yellow solution. Evaporation of this solution gave a yellow solid, which was purified by thin layer chromatography on a silica plate using 1:5 acetonitrile-benzene as the eluant. A major yellow band separated followed by an orangish yellow band which was extracted with acetonitrile. Evaporation of the extracts gave the $\left[R u_{2} L\left(L_{1}\right)_{4} \mathrm{Cl}_{4}\right]$ and $\left[R u\left(L_{1}\right)_{2}(d m s o)_{2} \mathrm{Cl}_{2}\right]$ complexes as yellow and orangish yellow solids respectively.

$\left[\mathrm{Ru}_{2} \mathrm{~L}\left(\mathrm{~L}_{1}\right)_{4} \mathrm{Cl}_{4}\right]$ : Yield: $63 \%$. Anal. Calc. for $\mathrm{C}_{38} \mathrm{H}_{38} \mathrm{~N}_{8} \mathrm{Cl}_{4} \mathrm{Ru}_{2}: \mathrm{C}, 47.99 ; \mathrm{H}, 4.00 ; \mathrm{N}, 11.78 \%$. Found: C, 47.72; H, 3.94; N, 11.69\%. Mass: $951[\mathrm{M}+\mathrm{H}]^{+}$. IR, $\mu, \mathrm{cm}^{-1}: 807$ and 1614 (C6H7N). ${ }^{1} \mathrm{H}$ NMR in $\mathrm{CDCl}_{3}$, (Overlapping signals are marked with an asterisk) $\delta$, ppm (J, Hz): $2.41\left(\mathrm{~s}, \mathrm{CH}_{3}\right), 7.09(\mathrm{~d}, 8 \mathrm{H}, J=7.9)$, $7.27(\mathrm{t}, 2 \mathrm{H}, J=7.2), 7.75-7.80(4 \mathrm{H})^{\star}, 8.16(\mathrm{~d}, 8 \mathrm{H}, J$ $=8.1), 8.41-8.43(4 \mathrm{H})^{*}$. 
$\left[\mathrm{Ru}\left(\mathrm{L}_{1}\right)_{2}(\mathrm{dmso})_{2} \mathrm{Cl}_{2}\right]$ :Yield: $24 \%$. Anal. Calc. for $\mathrm{C}_{16} \mathrm{H}_{26} \mathrm{~N}_{2} \mathrm{O}_{2} \mathrm{~S}_{2} \mathrm{Cl}_{2} \mathrm{Ru}$ : C, 37.35; $\mathrm{H}, 5.06 ; \mathrm{N}, 5.45 \%$. Found: C, 37.29; H, 5.02; N, 5.44\%. Mass: 515 $[\mathrm{M}+\mathrm{H}]^{+} . \mathrm{IR} \mu, \mathrm{cm}^{-1}: 802$ and $1606(\mathrm{C} 6 \mathrm{H} 7 \mathrm{~N}), 1085$ $(\mathrm{S}=\mathrm{O}) .{ }^{1} \mathrm{H} N M R$ in $\mathrm{CDCl}_{3} \delta$, ppm $(\mathrm{J}, \mathrm{Hz}): 3.10\left(\mathrm{~s}, \mathrm{CH}_{3}\right.$ of DMSO), 3.13 (s, $\mathrm{CH}_{3}$ of DMSO), $2.46\left(\mathrm{~s}, \mathrm{CH}_{3}\right.$ of 4-picoline), 7.10 (d, 4H, J=8.0), 8.18 (d, 4H, $J=$ 8.2).

\section{RESULTS AND DISCUSSION}

Reaction of $\left[\mathrm{Ru}(\mathrm{dmsO})_{4} \mathrm{Cl}_{2}\right]$ with bis-2,3-(2pyridyl)pyrazine ( $\mathrm{L}, \mathrm{I})$ proceeds smoothly in refluxing ethanol in the presence 4-picoline to afford a yellow and an orangish yellow complexes of the type $\left[\mathrm{Ru}_{2} \mathrm{~L}\left(\mathrm{~L}_{1}\right)_{4} \mathrm{Cl}_{4}\right]$ and $\left[\mathrm{Ru}\left(\mathrm{L}_{1}\right)_{2}(\mathrm{dmso})_{2} \mathrm{Cl}_{2}\right]$ respectively in decent yields. The reaction is presented in scheme 1. Preliminary characterizations (microanalytical and spectroscopic) of $\left[\mathrm{Ru}_{2} \mathrm{~L}\left(\mathrm{~L}_{1}\right)_{4} \mathrm{Cl}_{4}\right]$ indicate the presence of one coordinated bis-2,3-(2-pyridyl) pyrazine ligand bridging two ruthenium centers, four 4-picoline moieties and four chlorides in it. $\left[\mathrm{Ru}\left(\mathrm{L}_{1}\right)_{2}(\mathrm{dmso})_{2} \mathrm{Cl}_{2}\right]$ has two 4-picolines coordinated as monodentate ligands, two dimethylsulphoxides and two chlorides, bonded to the ruthenium center. Elemental analytical and spectroscopic (Mass, NMR, IR) data of the two complexes give a clear idea about their compositions.
Infrared spectra of both $\left[\mathrm{Ru}_{2} \mathrm{~L}\left(\mathrm{~L}_{1}\right)_{4} \mathrm{Cl}_{4}\right]$ and $\left[\mathrm{Ru}\left(\mathrm{L}_{1}\right)_{2}(\mathrm{dmso})_{2} \mathrm{Cl}_{2}\right]$ show many bands of varying intensities within $4000-400 \mathrm{~cm}^{-1}$. Assignment of each individual band to a specific vibration has not been attempted. Comparison with the spectrum of $\left[\mathrm{Ru}(\mathrm{dmsO})_{4} \mathrm{Cl}_{2}\right]$ shows the presence of some new bands (viz. 1505, 1479, $1060 \mathrm{~cm}^{-1}$ ) in the spectrum of $\left[\mathrm{Ru}_{2} \mathrm{~L}\left(\mathrm{~L}_{1}\right)_{4} \mathrm{Cl}_{4}\right]$, which are probably due to the coordinated bis-2,3-(2-pyridyl)pyrazine ligand. Two strong bands, observed near 800 and $1600 \mathrm{~cm}^{-1}$ in both the complexes, are attributed to the coordinated 4-picoline moiety. The signal corresponding to the sulphoxide group is observed around $1085 \mathrm{~cm}^{-1}$ in the $\left[\mathrm{Ru}\left(\mathrm{L}_{1}\right)_{2}(\mathrm{dmso})_{2} \mathrm{Cl}_{2}\right]$ complex.

The molecular formulae of the complexes have been further authenticated by their mass spectral data. Mass spectrum of $\left[\mathrm{Ru}_{2} \mathrm{~L}\left(\mathrm{~L}_{1}\right)_{4} \mathrm{Cl}_{4}\right]$ has been recorded and it is in well agreement with the speculated composition of the complex. In the mass spectrum of $\left[\mathrm{Ru}_{2} \mathrm{~L}\left(\mathrm{~L}_{1}\right)_{4} \mathrm{Cl}_{4}\right]$ the $[\mathrm{M}+\mathrm{H}]^{+}$peak appeared at 951 . Another prominent peak at 235 corresponded to the molecular weight of bis-2,3-(2-pyridyl)pyrazine with addition of a proton. In $\left[\mathrm{Ru}\left(\mathrm{L}_{1}\right)_{2}(\mathrm{dmsO})_{2} \mathrm{Cl}_{2}\right]$ the molecular ion peak is obtained at $515\left([\mathrm{M}+\mathrm{H}]^{+}\right)$.

Magnetic susceptibility measurements show that the $\left[R u_{2} L\left(L_{1}\right)_{4} \mathrm{Cl}_{4}\right]$ and $\left[\mathrm{Ru}\left(\mathrm{L}_{1}\right)_{2}(\mathrm{dmso})_{2} \mathrm{Cl}_{2}\right]$ complexes are diamagnetic, which corresponds to

Table 1: Electronic Spectral and Cyclic Voltammetric Data of the Complexes

\begin{tabular}{lccc}
\hline Complexes & $\begin{array}{c}\text { Electronic spectral data } \\
\lambda_{\text {max }}(\mathrm{nm})\left(\varepsilon / \mathrm{M}^{-1} \mathbf{c m}^{-1}\right)\end{array}$ & $\begin{array}{c}\text { Cyclic voltammetric data }^{\mathrm{b}} \\
\mathrm{E}, \mathrm{V} \text { vs. SCE } \\
\text { oxidative } \\
\text { responses }\end{array}$ & $\begin{array}{c}\text { reductive } \\
\text { responses }\end{array}$ \\
\hline$\left[\mathrm{Ru} \mathrm{L}_{2}\left(\mathrm{~L}_{1}\right)_{4} \mathrm{Cl}_{4}\right]$ & $\begin{array}{c}518(4900), 490(5000), \\
384^{\mathrm{c}}(3200), 288^{\mathrm{c}}(15400)\end{array}$ & $0.56^{\mathrm{d}}$ & $-0.99^{g}$ \\
{$\left[\mathrm{Ru}\left(\mathrm{L}_{1}\right)_{2}(\mathrm{dmsO})_{2} \mathrm{Cl}_{2}\right]$} & $258(38200), 302^{\mathrm{c}}(17400)$, & $0.46^{\mathrm{e}}(70)^{\mathrm{f}}$ & $-0.96^{\mathrm{g}}$ \\
& $432(31500)$ & & \\
\hline
\end{tabular}

\footnotetext{
a In dichloromethane solution.

b Solvent: 1:9 dichloromethane-acetonitrile; supporting electrolyte: TBAP; scan rate: $50 \mathrm{mVs}^{-1}$.

cShoulder.

${ }^{d} E_{p a}$ value, where $E_{p a}$ is the anodic peak potential.

${ }^{\text {e }} \mathrm{E}_{1 / 2}=0.5\left(\mathrm{E}_{\mathrm{pa}}+\mathrm{E}_{\mathrm{pc}}\right)$, where $\mathrm{E}_{\mathrm{pc}}$ is the cathodic peak potential.

${ }^{\mathrm{f}} \Delta \mathrm{E}_{\mathrm{p}}=\left(\mathrm{E}_{\mathrm{pa}}-\mathrm{E}_{\mathrm{pc}}\right)$.

${ }^{g} \mathrm{E}_{\mathrm{pc}}$ value.
} 
the +2 oxidation state of ruthenium (low-spin $d^{6}, S=$ 0 ) in them. ${ }^{1} \mathrm{H}$ NMR spectra of these complexes have been recorded in $\mathrm{CDCl}_{3}$ solution. In the spectrum of $\left[R u_{2} L\left(L_{1}\right)_{4} C l_{4}\right]$, signals for the methyl groups of the coordinated 4-picoline moieties were observed at 2.41 ppm corresponding to twelve hydrogen atoms.
The aromatic proton signals were observed as two distinct doublets in the expected region. Most of the proton signals from the coordinated bridging bis-2,3(2-pyridyl)pyrazine ligand, could be clearly identified. A distinct triplet could be observed at $7.27 \mathrm{ppm}$ with $\mathrm{J}=7.2$. The other expected signals viz. three

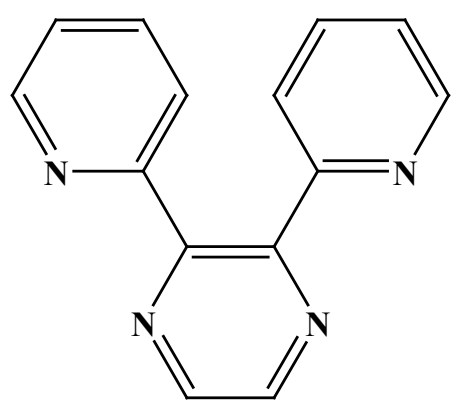

1. Ethanol, 4-picoline

2. $\left[\mathrm{Ru}(\mathrm{dmso})_{4} \mathrm{Cl}_{2}\right]$

4 hrs reflux

$\left[\mathrm{Ru}_{2} \mathrm{~L}\left(\mathrm{~L}_{1}\right)_{4} \mathrm{Cl}_{4}\right]+\left[\mathrm{Ru}\left(\mathrm{L}_{1}\right)_{2}(\mathrm{dmso})_{2} \mathrm{Cl}_{2}\right]$

3. TLC with $1: 5$

acetonitrile:toluene

Scheme 1: Reaction of bis-2,3-(2-pyridyl)pyrazine with $\left[\mathrm{Ru}(\mathrm{dmso})_{4} \mathrm{Cl}_{2}\right]$ in refluxing ethanol
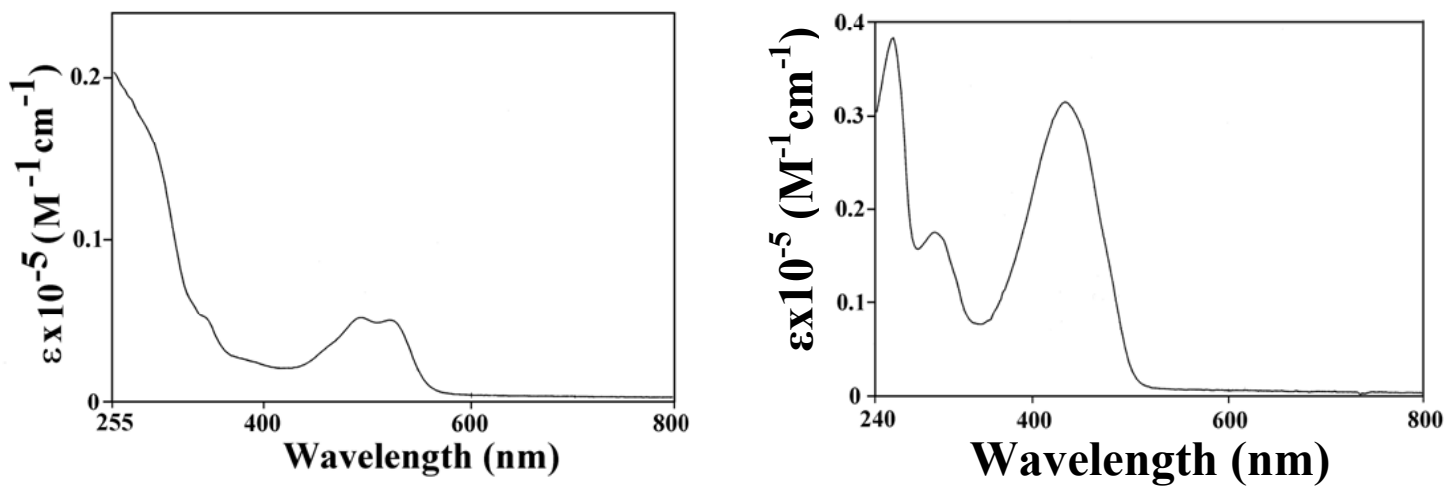

Fig. 1: Electronic spectrum of $\left[\mathrm{Ru}_{2} \mathrm{~L}\left(\mathrm{~L}_{1}\right)_{4} \mathrm{Cl}_{4}\right]$ (top) and $\left[\mathrm{Ru}\left(\mathrm{L}_{1}\right)_{2}(\mathrm{dmso})_{2} \mathrm{Cl}_{2}\right]$ (bottom)

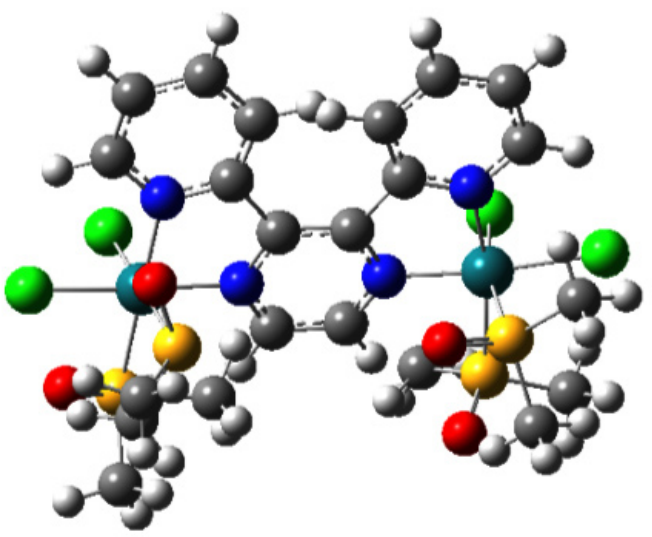

Fig. 2: DFT optimized structure of $\left[\mathrm{Ru}_{2} \mathrm{~L}\left(\mathrm{~L}_{1}\right)_{4} \mathrm{Cl}_{4}\right]$

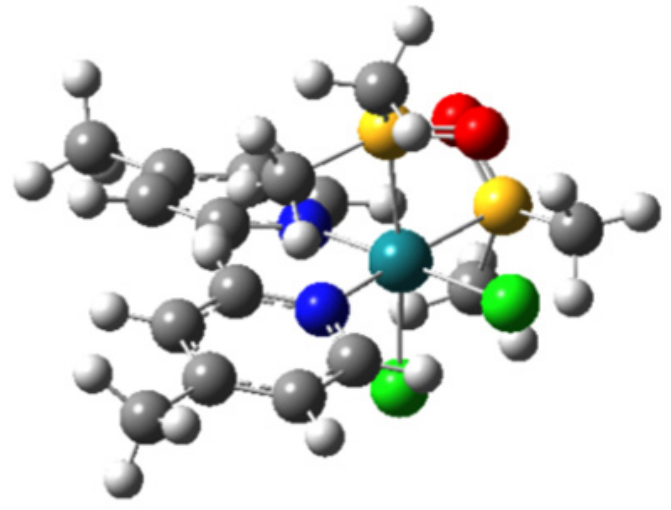

Fig. 3: DFT optimized structure of $\left[\mathrm{Ru}\left(\mathrm{L}_{1}\right)_{2}(\mathrm{dmsO})_{2} \mathrm{Cl}_{2}\right]$ 

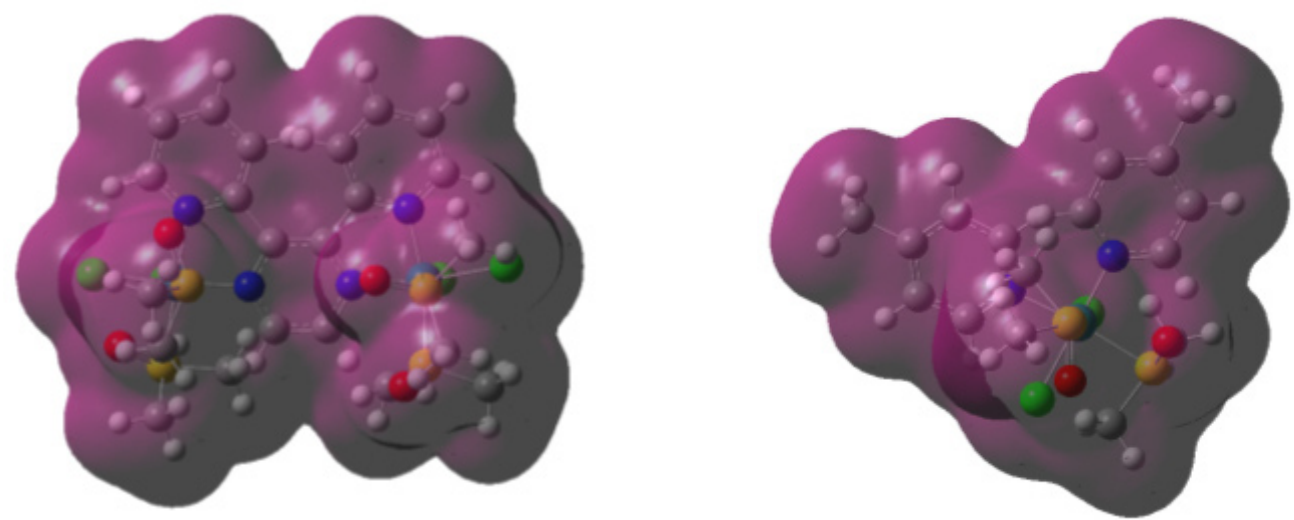

Fig. 4: Total electron density surfaces of $\left[\mathrm{Ru}_{2} \mathrm{~L}\left(\mathrm{~L}_{1}\right)_{4} \mathrm{Cl}_{4}\right]$ (top) and $\left[\mathrm{Ru}\left(\mathrm{L}_{1}\right)_{2}(\mathrm{dmso})_{2} \mathrm{Cl}_{2}\right]$ (bottom)

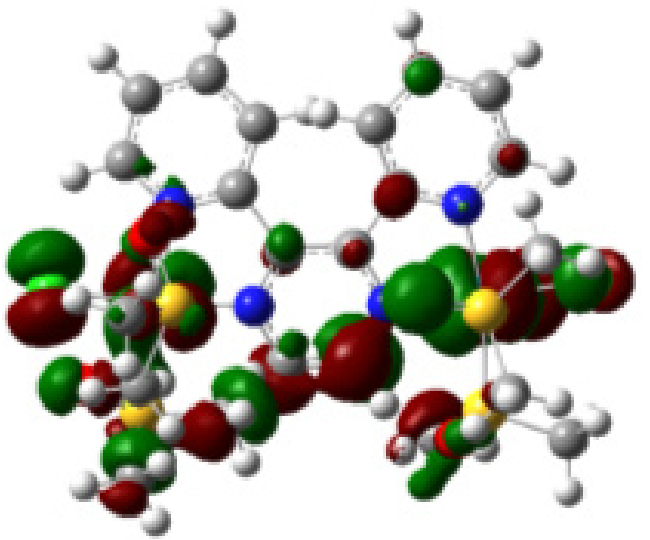

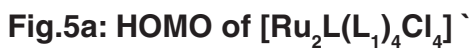

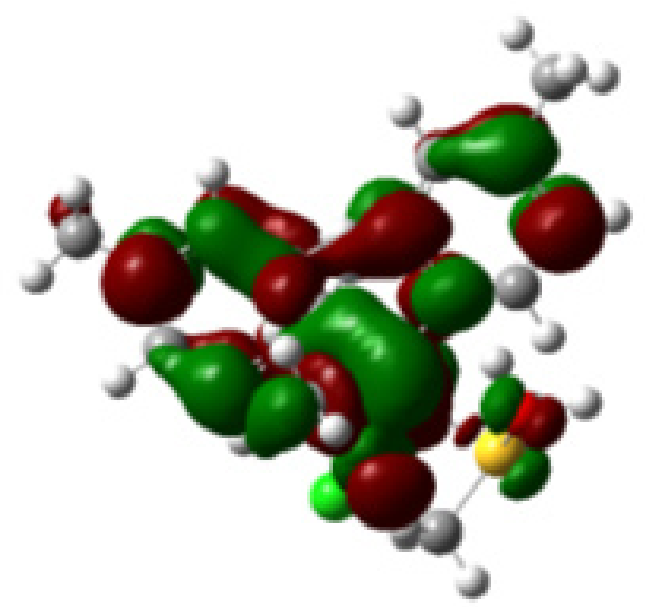

Fig.5c: $\mathrm{HOMO}$ of $\left[\mathrm{Ru}\left(\mathrm{L}_{1}\right)_{2}(\mathrm{dmsO})_{2} \mathrm{Cl}_{2}\right]$

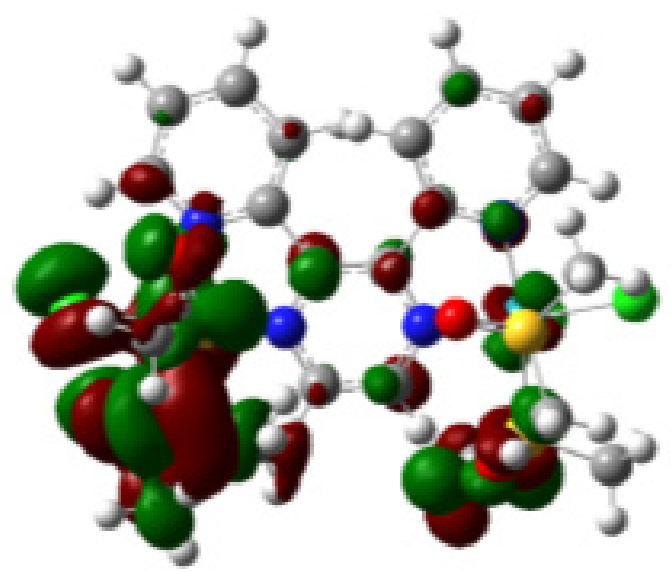

Fig. 5b: LUMO of $\left[\mathrm{Ru}_{2} \mathrm{~L}\left(\mathrm{~L}_{1}\right)_{4} \mathrm{Cl}_{4}\right]$

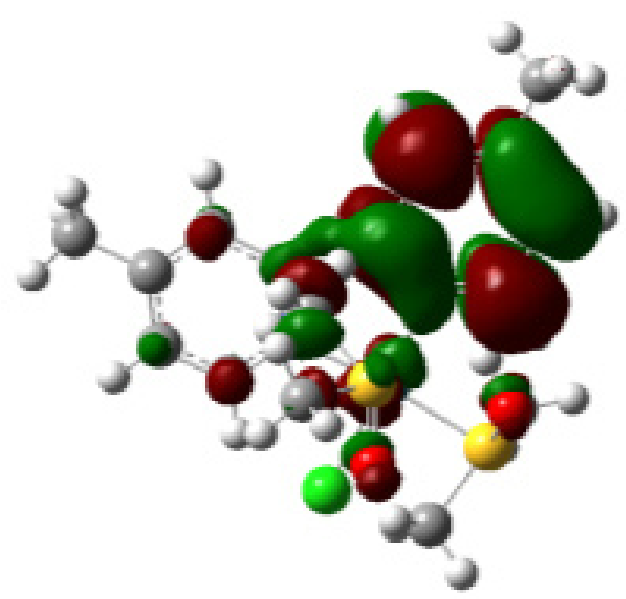

Fig. 5d: LUMO of $\left[R u\left(L_{1}\right)_{2}(d m s o)_{2} C l_{2}\right]$

Fig. 5: Frontier molecular orbitals of $\left[\mathrm{Ru}_{2} \mathrm{~L}\left(\mathrm{~L}_{1}\right)_{4} \mathrm{Cl}_{4}\right]$ (top) and $\left[\mathrm{Ru}\left(\mathrm{L}_{1}\right)_{2}(\mathrm{dmso})_{2} \mathrm{Cl}_{2}\right]$ (bottom) 

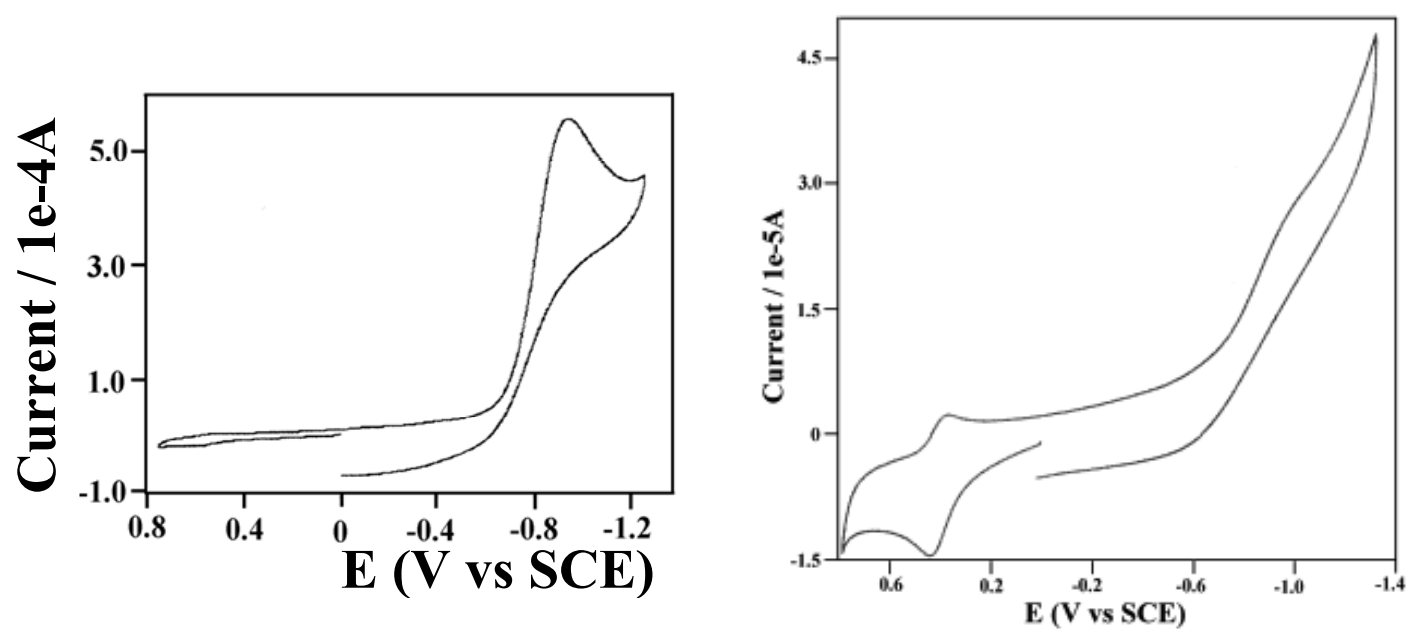

Fig. 6: Cyclic voltammogram of $\left.\left[\mathrm{Ru}_{2} \mathrm{~L}_{\left(\mathrm{L}_{1}\right.}\right)_{4} \mathrm{Cl}_{4}\right]$ (top) and $\left[\mathrm{Ru}\left(\mathrm{L}_{1}\right)_{2}(\mathrm{dmso})_{2} \mathrm{Cl}_{2}\right]$ (bottom) in 1:9 dichloromethane-acetonitrile solution (0.1 M TBAP) at a scan rate of $50 \mathrm{mV} \mathrm{s}^{-1}$

doublets and a triplet also appeared in an overlapped manner in the region 8.41-8.43 ppm and 7.75-7.80 $\mathrm{ppm}$. The spectrum of $\left[\mathrm{Ru}\left(\mathrm{L}_{1}\right)_{2}(\mathrm{dmso})_{2} \mathrm{Cl}_{2}\right]$ shows a distinct peak for the methyl protons of the bonded

Table 2: Selected Computed Bond Lengths (Å) and Angles $\left({ }^{\circ}\right)$ for the Complexes

\begin{tabular}{|c|c|c|c|}
\hline \multicolumn{4}{|c|}{$\begin{array}{c}{\left[\mathrm{Ru}_{2} \mathrm{~L}\left(\mathrm{~L}_{1}\right)_{4} \mathrm{Cl}_{4}\right]} \\
\text { Bond Lengths }(\AA)\end{array}$} \\
\hline Ru1-Cl1 & 2.22892 & Ru1-S1 & 2.25044 \\
\hline Ru1-Cl2 & 2.22811 & Ru1-S2 & 2.23786 \\
\hline Ru1-N1 & 1.93713 & Ru2-S3 & 2.24733 \\
\hline Ru1-N2 & 1.94437 & Ru2-S4 & 2.25153 \\
\hline $\mathrm{Ru} 2-\mathrm{Cl} 3$ & 2.22908 & & \\
\hline $\mathrm{Ru} 2-\mathrm{Cl} 4$ & 2.22928 & & \\
\hline Ru2-N3 & 1.94089 & & \\
\hline Ru2-N4 & 1.96289 & & \\
\hline \multicolumn{4}{|c|}{ Bond Angles ( ${ }^{\circ}$ ) } \\
\hline N2-Ru1-S2 & 179.1 & N4-Ru2-S4 & 168.7 \\
\hline N1-Ru1-Cl1 & 176.8 & N3-Ru2-Cl3 & 172.9 \\
\hline Cl2-Ru1-S1 & 179.6 & Cl4-Ru2-S3 & 167.1 \\
\hline N1-Ru1-N2 & 83.6 & N3-Ru2-N4 & 81.7 \\
\hline \multicolumn{4}{|c|}{$\begin{array}{l}{\left[\mathrm{Ru}\left(\mathrm{L}_{1}\right)_{2}(\mathrm{dmso})_{2} \mathrm{Cl}_{2}\right]} \\
\text { Bond Lengths }(\AA)\end{array}$} \\
\hline $\mathrm{Ru}-\mathrm{Cl} 1$ & 2.23016 & Ru-S1 & 2.25026 \\
\hline $\mathrm{Ru}-\mathrm{Cl} 2$ & 2.23021 & Ru-S2 & 2.25021 \\
\hline Ru-N1 & 1.94041 & & \\
\hline Ru-N2 & 1.93948 & & \\
\hline \multicolumn{4}{|c|}{ Bond Angles $\left(^{\circ}\right)$} \\
\hline N1-Ru-Cl1 & 179.2 & Cl2-Ru-S1 & 174.3 \\
\hline N2-Ru-S2 & 174 & & \\
\hline
\end{tabular}

4-picoline group at $2.46 \mathrm{ppm}$. Two clear doublets corresponding to the aromatic protons of the ligand were seen at 8.18 and $7.10 \mathrm{ppm}$. The methyl protons of the coordinated dimethylsulfoxides also appear as two distinct singlets around $3.10 \mathrm{ppm}$ and 3.13 ppm. Thus the ${ }^{1} \mathrm{H}$ NMR spectra of the complexes correlates well with their compositions.

The $\left[R u_{2} L\left(L_{1}\right)_{4} \mathrm{Cl}_{4}\right]$ and $\left[\mathrm{Ru}\left(\mathrm{L}_{1}\right)_{2}(\mathrm{dmso})_{2} \mathrm{Cl}_{2}\right]$ complexes are readily soluble in dichloromethane, chloroform, acetone, etc., and sparingly soluble in methanol, ethanol, acetonitrile, etc., producing yellow and orangish yellow solutions respectively. Electronic spectra of the complexes have been recorded in dichloromethane solution. Spectra of the complexes are shown in figure 1 and spectral data are presented in table 1. The complexes show several intense absorptions in the visible and ultraviolet region. The absorptions in the ultraviolet region are due to transition within the ligand orbitals. To have an insight into the nature of absorptions in the visible region, DFT calculations have been performed after the structures of the $\left[\mathrm{Ru}_{2} \mathrm{~L}\left(\mathrm{~L}_{1}\right)_{4} \mathrm{Cl}_{4}\right]$ and $\left[\mathrm{Ru}\left(\mathrm{L}_{1}\right)_{2}(\mathrm{dmso})_{2} \mathrm{Cl}_{2}\right]$ complexes were optimized. The DFT optimized structure of $\left[\mathrm{Ru}_{2} \mathrm{~L}\left(\mathrm{~L}_{1}\right)_{4} \mathrm{Cl}_{4}\right]$ is shown in figure 2 and that of $\left[\mathrm{Ru}\left(\mathrm{L}_{1}\right)_{2}(\mathrm{dmso})_{2} \mathrm{Cl}_{2}\right]$ is displayed in figure 3 . The computed bond parameters are presented in table 2 .

The contour plots of the total electron density of the molecules are shown in figure 4. In the complex $\left[\mathrm{Ru}_{2} \mathrm{~L}\left(\mathrm{~L}_{1}\right)_{4} \mathrm{Cl}_{4}\right]$, the highest occupied 
Table 3: Composition of Frontier Molecular Orbitals of the Complexes

\begin{tabular}{cccc}
\hline Complexes & $\begin{array}{c}\text { Contributing } \\
\text { Fragments }\end{array}$ & $\begin{array}{c}\text { \% Contribution of fragments to } \\
\text { HOMO }\end{array}$ & $\begin{array}{c}\text { LUMO } \\
\end{array}$ \\
\hline$\left[\mathrm{Ru}_{2} \mathrm{~L}\left(\mathrm{~L}_{1}\right)_{4} \mathrm{Cl}_{4}\right]$ & $\mathrm{Ru}$ & 52 & 06 \\
& Bis-2,3-(2-pyridyl)pyrazine & 06 & 08 \\
& 4-picoline & 34 & 81 \\
{$\left[\mathrm{Ru}\left(\mathrm{L}_{1}\right)_{2}(\mathrm{dmsO})_{2} \mathrm{Cl}_{2}\right]$} & $\mathrm{Ru}$ & 55 & 10 \\
& 4-picoline & 32 & 84 \\
\hline
\end{tabular}

molecular orbital (HOMO) is found to be localized primarily $(52 \%)$ on the ruthenium metal center, with much less contribution (06\%) from bis-2,3-(2-pyridyl) pyrazine ligand. However, the HOMO has notable contribution from the coordinated 4-picoline moiety (34\%). The lowest unoccupied molecular orbital (LUMO) is observed to have less $(06 \%)$ ruthenium character and dominant (81\%) 4-picoline ligand character. The contribution from the coordinated bis-2,3-(2-pyridyl)pyrazine ligand is also insignificant (08\%). In the complex $\left[\mathrm{Ru}\left(\mathrm{L}_{1}\right)_{2}(\mathrm{dmso})_{2} \mathrm{Cl}_{2}\right] \mathrm{HOMO}$ has major contribution from the ruthenium center (55\%) while the coordinated 4-picoline ligand contributes $32 \%$. The LUMO has substantial contribution from the bonded 4-picoline ligand (84\%). Contour plots of the HOMO and LUMO of the complexes are shown in figure 5 and compositions of these orbitals are given in table 3 . The lowest-energy absorption in the visible region in all these complexes is therefore assignable to a transition from a filled ruthenium orbital to a vacant $\pi^{*}$-orbital of 4 -picoline. The lowest energy absorption for the complexes is thus, supposed to be a metal-to-ligand charge transfer (MLCT) transition.

Electrochemical properties of the complexes have been studied by cyclic voltammetry in 1:9 dichloromethane-acetonitrile solution in 0.1 M TBAP (a little dichloromethane was necessary to take the complex into solution. Addition of large excess of acetonitrile was necessary to record the redox responses in proper shape). Voltammetric data are given in table 1 and the voltammograms are shown in figure 6. In $\left[\mathrm{Ru}_{2} \mathrm{~L}\left(\mathrm{~L}_{1}\right)_{4} \mathrm{Cl}_{4}\right]$ an irreversible oxidation is observed on the positive side of SCE whereas in $\left[\mathrm{Ru}\left(\mathrm{L}_{1}\right)_{2}(\mathrm{dmso})_{2} \mathrm{Cl}_{2}\right]$ the oxidation is reversible in nature characterized by a peak-to-peak separation $\left(D E_{p}\right)$ of $70 \mathrm{mV}$, which remains unchanged upon changing the scan rate, and the anodic peak-current $\left(i_{p a}\right)$ is almost equal to the cathodic peak-current $\left(i_{p c}\right)$. In view of the composition of $\mathrm{HOMO}$, the oxidation is believed to be a $R u(I I)-R u(I I I)$ oxidation. Since the two metals are in a symmetric environment in $\left[\mathrm{Ru}_{2} \mathrm{~L}\left(\mathrm{~L}_{1}\right)_{4} \mathrm{Cl}_{4}\right]$ one oxidation peak has been observed. One-electron nature of this oxidation has been confirmed by comparing its current height with that of standard ferrocene-ferrocenium couple under identical experimental conditions. The reductive response is irreversible in nature in both the complexes and shows non-stoichiometric current $\left(\mathrm{i}_{\mathrm{pc}}\right)$. Based on the composition of LUMO, the reduction is assigned to the reduction of the coordinated 4-picoline ligand.

In summary, the present study shows that the nitrogen containing heterocyclic ligand bis-2,3-(2pyridyl)pyrazine reacts smoothly with $\left[\mathrm{Ru}(\mathrm{dmso})_{4} \mathrm{Cl}_{2}\right]$ producing stable mixed ligand complexes where the ligand remains coordinated as a bridging $\mathrm{N}, \mathrm{N}$ donor. It also indicates that $\left[\mathrm{Ru}(\mathrm{dmso})_{4} \mathrm{Cl}_{2}\right]$ has the potential to react similarly with other nitrogen containing heterocycles and such reactions would be explored in the future.

\section{ACKNOWLEDGEMENTS}

The present work has been supported by University Grants Commission (Reference No.: PSW118/12-13 dated 01.03.2013; Serial No.: 214379) which is gratefully acknowledged. The author is also indebted to the Department of Chemistry, Taki Government College, Taki, West Bengal, India. 


\section{REFERENCES}

1. Zhang, D.; Wang, Q. Coord. Chem. Rev., 2015, 300, 29.

2. Amesano, F.; Pannunzio, A.; Coluccia, M.; Natile, G. Coord. Chem. Rev., 2015, 284, 286.

3. Huang, L.; Arndt, M.; Gooben, K.; Heydt, H.; Cooben, L. J. Chem. Rev., 2015, 115(7), 2596.

4. Omae, I. Coord. Chem. Rev., 2014, 280, 84.

5. Corey, J.Y. Chem. Rev., 2011, 111(2), 863.

6. Poyatos, M.; Mata, J. A.; Peris, E. Chem. Rev., 2009, 109(8), 3677.

7. Ofele, K.; Tosh, E.; Taubmann, C.; Herrmann, W. A. Chem. Rev., 2009, 109(8), 3408.

8. Shimazaki, Y.; Yajima, T.; Takani, M.; Yamauchi, O. Coord. Chem. Rev., 2009, 253(3-4), 479.

9. Shivaramakrishna, A.; Clayton, H. S.; Makhubela, B. C. E.; Moss, J. R. Coord. Chem. Rev., 2008, 252(12-14), 1460.

10. Mohr, F.; Priver, S, H.; Bhargava, S. K.; Bennet, M. A. Coord. Chem. Rev., 2006, 250(15-16), 1851.

11. Quiroga, A. G.; Ranninger, C. N. Coord. Chem. Rev., 2004, 248(1-2), 119.

12. Phillips, A. D.; Gonsalvi, L.; Romerosa, A.; Vizza, F.; Peruzzini, M. Coord. Chem. Rev., 2004, 248(11-12), 955.

13. El-Habeeb, A. A. Orient. J. Chem., 2014, 30(4), 1441.

14. Marandi, F.; Marandi, A.; Ghadermazi, M.; Krautscheid, H.; Rafiee, M. Coord. Chem., 2012, 65(11), 1882.

15. White, T. A.; Rangan, K.; Brewer, K. J. J. of Photochemistry and Photobiology A: Chemistry, 2010, 209(2-3), 203.

16. Arachchiges, S. M.; Brown, J.; Brewer, K. J. J. of Photochemistry and Photobiology A: Chemistry, 2008, 197(1), 13.

17. Machado, R. A.; Goite, M. C.; Rivillo, D.; De Sanctis, Y.; Arce, A. J.; Deeming, A. J.; D'Ornelas, L.; Sierralta, A.; Atencio, R.; Teresa, G.; Galarza, E. J. Organomet. Chem., 2007, 692, 894.

18. Hsu, G-Y.; Chen, C-W.; Cheng, S-C.; Lin, S-H.; Wei, H-H.; Lee, C-J. Polyhedron, 2005, 24, 487.

19. Zong, R.; Thummel, R. P. J. Am. Chem. Soc., 2005, 127(37), 12802.
20. Abrahamsson, M.; Wolpher, H.; Johanson, O. Larsson, J.; Krtikos, M.; Erikkson, L.; Norrby, P-O.; Bergquist, J.; Sun, L.; Akermark, B.; Hammerstrom, L. Inorg. Chem., 2005, 44(9), 3215.

21. Hotze, A. C. G.; Caspers, S. E.; de Vos. D.; Kooijman, H.; Spok, A. L.; Flamigni, A.; Bacac, M.; Sava, G.; Haasnoot, J. G.; Reedijk, J. J. Biol. Inorg. Chem., 2004, 9, 354.

22. Chelucci, G.; Baldino, S.; Baratto, W. Coord. Chem. Rev., 2015, 300, 29.

23. Sun, Q.; Mosquera-Vazquez, S.; Suffren, Y.; Hankache, J.; Amstutz, N.; Daka, L.M.L.; Vauthey, E.; Hauser, A. Coord. Chem. Rev., 2015, 282-283, 87.

24. Keshavarz, E.; Tabatabaeian, K.; Mamaghani, M.; Mahmoodi, N. O. Orient J. Chem., 2015, 31(4), 2189.

25. Pandey, R. N.; Kumari, N. Orient J. Chem., 2014, 30(4), 2105.

26. Younus, H.A.; Ahmed, N.; Su, N.; Verpoort, F. Coord. Chem. Rev., 2014, 153-157, 112.

27. Machura, B.; Wolff, M.; Gryca, I. Coord. Chem. Rev., 2014, 275, 154.

28. Singh, A.K.; Pandey, D.; Xu, Q.; Braunstein, P. Coord. Chem. Rev., 2014, 270-271, 31.

29. Stacchiola, D. J.; Senanayake, S. D.; Liu, P.; Rodriguez, J. A. Chem. Rev., 2013, 113(6), 4473.

30. Kumar, A. Orient J. Chem., 2013, 29(2), 815.

31. Adekunle, F. A. O.; Semire, B.; Odunola, O. A. Orient J. Chem., 2013, 29(3), 945.

32. Over, H. Chem. Rev., 2012, 112(6), 3356.

33. Ruggi, A.; van Leeuwen, F. W. B.; Velders, A. H. Coord. Chem. Rev., 2011, 255(21-22), 2542.

34. Alcaide, B.; Almendros, P.; Luna, A. Chem. Rev., 2009, 109(8), 3817.

35. Kabir, S. E.; Hogarth, G. Coord. Chem. Rev., 2009, 253(9-10), 1285.

36. Shivaramakrishna, A.; Clayton, H. S.; Makhubela, B. C. E.; Moss, J. R. Coord. Chem. Rev., 2008, 252 (12-14), 1460.

37. Puntoriero, F.; Campagna, S.; Stadler, A-M.; Lehn, J-M. Coord. Chem. Rev., 2008, 252(2324), 2480.

38. Rilteng, V.; Sirlin, C.; Pfeffer, M. Chem. Rev., 
2002, 102 (5), 1731.

39. Baraldo, L. M.; Forlano, P.; Parise, A. R.; Slep, L. D.; Olabe, J. A.Coord. Chem. Rev., 2001, 219-221, 2881.

40. Ji, L. N.; Zou, X-H.; Liu, J-G. Coord. Chem. Rev., 2001, 216-217, 513.

41. Dragutan, V.; Dragutan, I.; Delaude, L.; Demonceau, A. Coord. Chem. Rev., 2001, 251(5-6), 765.

42. Evans, I. P.; Spencer, A.; Wilkinson, G. J. Chem. Soc. Dalton Trans, 1973, 204.

43. Walter, M.; Ramaley, L. Anal. Chem., 1973, 45, 165

44. Sawyer, D. T.; Roberts, J. L. Jr. Experimental Electrochemistry for Chemists, Wiley, New York, 1974, 167-215.

45. Frisch, M. J.; Tracks, G. W.; Schlegel, H. B.; Scuseria, G. E.; Robb, M. A.; Cheeseman Jr., J. R.; Montgomery, J. A.; Vreven, T.; Kudin, K. N.; Burant, J. C.; Millam, J. M.; lyengar, S. S.; Tomasi, J.; Barone, V.; Mennucci, B.; Cossi,
M.; Scalamani, G.; Rega, N.; Petersson, G. A.; Nakatsuji, H.; Hada, M.; Ehara, M.; Toyota, K.; Fukuda, R.; Hasegawa, I.; Ishida, M.; Nakajima, T.; Honda, Y.; Kitao, O.; Nakai, H.; Klene, M.; Li, X.; Knox, J. E.; Hratchian, H. P.; Cross, J. B.; Bakken, V.; Adamo, C.; Jaramillo, J.; Gomperts, R.; Stratmann, R.E.; Yazyev, O.; Austin, A. J.; Cammi, R.; Pomelli, C.; Ochterski, J. W.; Ayala, P.Y.; Morokuma, K.; Voth, G. A.; Salvador, P.; Dannenberg, J. J.; Zakrzewski, V. G.; Dapprich, S.; Daniels, A. D.; Strain, M. C.; Farkas, O.; Malick, D. K.; Rabuck, A. D.; Raghavachari, K.; Foresman, J. B.; Ortiz, J. V.; Cui, Q.; Baboul, A. G.; Clifford, S.; Cioslowski, J.; Stefanov, B. B.; Liu, G.; Liashenko, A.; Piskroz, P.; Komaromi, I.; Martin, R. L.; Fox, D. J.; Keith, T.; Al-Laham, M. A.; Peng, C. Y.; Nanayakkara, A.; Challacombe, M.; Gill, P. M. W.; Johnson, B.; Chen, W.; Wong, M. W.; Gonzalez, C.; Pople, J. A.; Gaussian 03, revision D01-0; Gaussian Inc.: Pittsburgh, PA, 2003. 